TT Revista del instituto de ciencias JuRídicAs DE PUEBLA. MÉXICO. ISSN 1870-2147. NUEVA ÉPOCA VOL. 11, No. 39. ENERO - JUNIO DE 2017. PP9-23

\title{
El derecho a conocer el origen genético de las personas nacidas mediante técnicas de reproducción humana asistida con donante anónimo*
}

\section{Rosalía Muñoz Genestoux** Leonardo Raúl Víttola***}

\section{RESUMEN}

En el presente analizaremos el derecho a conocer los origenes en las técnicas de reproducción humana asistida, sus alcances e implicancias a la luz del derecho a la identidad, y su cruce con el derecho a la intimidad de los donantes. Se resalta que las legislaciones deben equilibrar los derechos humanos con el respeto y garantiade su ejercicio.

PALABRAS CLAVE: Identidad, Intimidad, Información, Donante, Orígenes, TRHA.

\begin{abstract}
In the present work we analyze the right to know origins in assisted human reproduction techniques, their scopes and implications in the light of the right to identity, and its crossing with the right to privacy of donors. It is highlighted that legislations must balance human rights with the respect and guarantee of the exercise.
\end{abstract}

KEY WORDS: Anonymity, right, identity, privacy, information, donor, origins

\footnotetext{
* Artículo recibido el 7 de septiembre de 2016 y aceptado el 14 de noviembre de 2016

**Abogada, especialista en derecho de familia, Universidad de Buenos Aires. rosaliamunoz@gmail.com

***Abogado, maestrando en derecho de familia, Universidad de Buenos Aires. vittolaleonardo@hotmail.com
} 


\section{SUMARIO}

1. Introducción

2. El derecho a conocer los orígenes como derecho humano

3. Secreto y anonimato. Intereses en conflicto

4. Diferentes posturas legislativas

5. Postura del Código Civil y Comercial Argentino

6. Palabras de cierre

\section{Introducción}

En los últimos años, nuestra sociedad viene dando grandes pasos hacia el reconocimiento legal de diversas formas de organización familiar impensables en otro momento histórico. Estas nuevas realidades sociales y modelos de familia muchas veces ponen en jaque a las legislaciones, pues exigen nuevas respuestas frente a nuevos interrogantes.

Uno de los temas más debatidos al momento de legislar ha sido, y sigue siendo en la actualidad, el derecho a conocer los origenes de los hijos nacidos por técnicas de reproducción humana asistida, ${ }^{1}$ más precisamente aquellas técnicas heterólogas (con material genético de un tercero) o, incluso, en la gestación por sustitución. Sólo en esos supuestos existe una disociación originaria entre el elemento genético y el biológico. Éstas dejan fuera a las técnicas homólogas, toda vez que esos datos coinciden, desde sus inicios, en un pie de igualdad, con la filiación por naturaleza.

Existe un derecho a conocer el origen genético y otro a conocer el origen biológico. Si bien en un principio ambos conceptos se han tratado como sinónimos, el arribo de las TRHA ha permitido su disociación. Desde el punto de vista genético, el enfoque estará puesto en el donante de gametos que ha posibilitado el nacimiento. En cambio, el origen biológico alude al bios -vida- de la persona. Tiene una connotación mucho más amplia, en la cual quedaría incluida la gestación por sustitución, pues la gestante es quien lo tuvo y lo parió; por tanto, forma parte de su historia.

El derecho a conocer los orígenes biológicos ha sido objeto de estudio por parte de la doctrina argentina dentro del desarrollo del instituto de la adopción. Como decimos, ha existido un bios detrás, cuestión que difiere notablemente con el uso de las TRHA heterólogas, donde puede verse claramente que no existe un bios, sino simplemente un dato genético. Debido a ello, partimos de que el

\footnotetext{
${ }^{1}$ En adelante TRHA.
} 
tratamiento que deben realizar las legislaciones al derecho a conocer los orígenes debe ser distinto para las técnicas de reproducción asistida.

Ya el derecho internacional se ha ocupado de fijar los límites entre distinciones que guardan una justificación objetiva y las que no. El punto de partida lo ha dado el Tribunal Europeo de Derechos Humanos (TEDH) al decir que no toda diferencia de trato es discriminatoria, y que un trato igualitario no implica un trato idéntico. ${ }^{2}$ El trato idéntico a personas desiguales es tan discriminatorio como tratar a personas iguales de manera diferente. Deben darse dos requisitos clave para que una distinción que plantee la norma no sea discriminatoria: a) tener una justificación objetiva y razonable o, en otras palabras, perseguir un fin legítimo; y b) debe existir una relación razonable de proporcionalidad entre la finalidad y el medio empleado para lograrla. ${ }^{3}$ Esta fórmula, desde un punto de vista teórico, es indiscutible para establecer los límites entre distinciones justificadas y las que no. La definición señalada es conteste con los requisitos mencionados; guarda toda distinción legislativa a la proporcionalidad exigida para que no se torne discriminatoria.

Tomando esto como punto de partida, ahondaremos en el análisis del entrecruzamiento del derecho a conocer el origen genético con el derecho a la intimidad de los donantes anónimos. El objeto es brindar pautas para la adopción o modificación de las legislaciones que equilibren ambos derechos ante la presencia de un sistema de anonimato para las donaciones.

\section{El derecho a conocer los orígenes como derecho humano}

En primer lugar, cabe señalar que el derecho a conocer los orígenes se encuentra comprendido dentro del derecho humano a la identidad. El jurista peruano Carlos Fernández Sessarego ha definido a la identidad como el "conjunto de atributos y características que permiten individualizar a la persona en sociedad [...] es todo aquello que hace que cada cual sea uno mismo y no otro". ${ }^{4}$ Dicha

\footnotetext{
${ }^{2}$ Cfr. Belgium Linguistics Case, 'In the case "relating to certain aspects of the laws on the use of languages in education in Belgium" v Belgium' (Application no 1474/62; 1677/62; 1691/62; 1769/63; 1994/63; 2126/64), 23 de julio de 1968.

${ }^{3}$ Interpretando el artículo 14 de la CEDH, el Tribunal Europeo de Derechos Humanos ha dicho lo siguiente: "El principio de igualdad de trato se viola cuando la distinción no tiene justificación objetiva y razonable. La existencia de tal justificación debe evaluarse en relación con la finalidad y los efectos de la medida involucrada, habida consideración de los principios que normalmente imperan en las sociedades democráticas. Una diferencia de trato en el ejercicio de un derecho reconocido en la Convención no sólo debe perseguir una finalidad legítima; el artículo 14 se infringe igualmente cuando se establece claramente que no hay relación razonable de proporcionalidad entre los medios empleados y los fines que se busca lograr".

${ }^{4}$ Fernández Sessarego, Carlos, Derecho a la Identidad personal, Argentina, Astrea, 1992, p. 113.
} 
definición pone énfasis en que la identidad no finaliza con la información que se obtiene de la faz estática, sino que continúa y se construye con el conjunto de valores espirituales que conforman la personalidad de cada persona.

Según la Corte Interamericana de Derechos Humanos (CIDH),, "el derecho a la identidad puede ser conceptualizado, en general, como el conjunto de atributos y características que permiten la individualización de la persona en sociedad y, en tal sentido, comprende varios otros derechos según el sujeto de derechos de que se trate y las circunstancias del caso". ${ }^{6}$ Si bien el mismo no se encuentra expresamente contemplado en la Convención Americana de Derechos Humanos, la cIDH tiene dicho que la violación a tal derecho debe interpretarse a la luz del corpus iuris internacional.

El artículo 29 establece que "ninguna disposición de la presente Convención puede ser interpretada en el sentido de [...] c) excluir otros derechos y garantías que son inherentes al ser humano o que se derivan de la forma democrática representativa de gobierno". De tal manera, se abre la puerta a la Convención sobre los Derechos del Niño, que lo regula en forma expresa, para dar respuesta al tema -en el entendimiento que no es un derecho propio de los niños, sino que es propio de la condición humana-. ${ }^{7}$ La misma reconoce expresamente el derecho a la identidad en su artículo 8, el cual dice:

1. Los Estados Partes se comprometen a respetar, el derecho del niño a preservar su identidad, incluidos la nacionalidad, el nombre y las relaciones familiares de conformidad con la ley sin injerencias ilícitas. 2. Cuando un niño sea privado ilegalmente de algunos de los elementos de su identidad o de todos ellos, los Estados Partes deberán prestar la asistencia y protección apropiadas con miras a restablecer rápidamente su identidad.

La CIDH, en consonancia con el artículo 29 de la Convención Americana de Derechos Humanos, le otorga una extensión mayor al derecho a la identidad contenido en el artículo 8 de la cDN, pues, en definitiva, es un derecho humano de las personas que debe respetarse en todas las etapas de su vida. Por su parte, la Asamblea General de la Organización de Estados Americanos ${ }^{8}$ señaló:

El reconocimiento de la identidad de las personas es uno de los medios a través del cual se facilita el ejercicio de los derechos a la personalidad jurídica,

\footnotetext{
${ }^{5}$ En adelante, $\mathrm{CIDH}$.

${ }^{6} \mathrm{CIDH}$, Gelman vs. Uruguay, 24 de febrero, 2011. Disponible en: http://www.corteidh.or.cr/cf/jurisprudencia2/ficha_ tecnica.cfm?lang=en\&tnld_Ficha $=345$

${ }^{7}$ CIDH, Contreras y otros vs. El Salvador, 31 de agosto, 2011. Disponible en: http://corteidh.or.cr/docs/casos/articulos/ seriec_232_esp.pdf

${ }^{8}$ En adelante, OEA.
} 
al nombre, a la nacionalidad, a la inscripción en el registro civil, a las relaciones familiares, entre otros derechos reconocidos en instrumentos internacionales como la Declaración Americana de los Derechos y Deberes del Hombre y la Convención Americana. ${ }^{9}$

Asimismo, señaló que "la falta de reconocimiento de la identidad puede implicar que la persona no cuenta con constancia legal de su existencia, lo cual dificulta el pleno ejercicio de sus derechos civiles, políticos, económicos, sociales y culturales". ${ }^{10}$ En ese mismo sentido, el Comité Jurídico Interamericano expresó que el "derecho a la identidad es consustancial a los atributos y a la dignidad humana” y que, en consecuencia, "es un derecho humano fundamental oponible erga omnes como expresión de un interés colectivo de la comunidad internacional en su conjunto, que no admite derogación ni suspensión en los casos previstos por la Convención Americana". ${ }^{11}$

Si nos alejamos del Sistema Interamericano de Derechos Humanos, vemos que también el Tribunal Europeo de Derechos Humanos se ha encargado de destacar la importancia del conocimiento de los orígenes, consolidando el conocimiento como un derecho esencial para desarrollar la propia identidad que forma parte del derecho a la vida privada familiar reconocido en el artículo 8 del Convenio Europeo de Derechos Humanos. ${ }^{12}$

Como podemos observar, la identidad está compuesta de una faz dinámica y de una faz estática. Esta última está compuesta de varios elementos, cada uno de los cuales desempeña un papel en la construcción dinámica de la identidad

\footnotetext{
${ }^{9}$ Sobre ese aspecto el Comité Jurídico Interamericano consideró que la Convención Americana sobre Derechos Humanos, si bien no consagra el derecho a la identidad bajo ese nombre expresamente, sí incluye, como se ha visto, el derecho al nombre, el derecho a la nacionalidad y el derecho relativo a la protección de la familia. OEA, "Programa Interamericano para el Registro Civil Universal y 'Derecho a la Identidad'", resolución AG/RES. 2286. OEA, "Programa Interamericano para el Registro Civil Universal y 'Derecho a la Identidad'", resolución AG/RES. 2362. OEA, "Programa Interamericano para el Registro Civil Universal y 'Derecho a la Identidad'", resolución AG/RES. 2602.

${ }^{10}$ OEA, "Programa Interamericano para el Registro Civil Universal y 'Derecho a la Identidad'", resolución AG/RES. 2286. OEA, "Programa Interamericano para el Registro Civil Universal y 'Derecho a la Identidad'", resolución AG/RES. 2362. OEA, "Programa Interamericano para el Registro Civil Universal y 'Derecho a la Identidad'", OEA, "Programa Interamericano para el Registro Civil Universal y 'Derecho a la Identidad"', OEA, "Programa Interamericano para el Registro Civil Universal y 'Derecho a la Identidad'", resolución AG/RES. 2602.

"Comité Jurídico Interamericano, "Opinión sobre el alcance del derecho a la identidad", 710 Período ordinario de sesiones, Documento CJI/doc. 276/07 Río de Janeiro, Brasil, rev. 1, de 10 de agosto de 2007.

${ }^{12}$ En el caso Rose vs. Secretary of State for Health and Human Fertilisation and Embriology Authority, High Court of Justice, Queen's Bench División, del 26 de julio de 2002, se concluyó que tanto en las personas nacidas mediante TRHA heteróloga, con donación de gametos, como en el caso de personas adoptadas, está en juego la vida privada familiar. "Un ser humano es un ser humano, con independencia de las circunstancias de su concepción y uno concebido mediante inseminación artificial con gametos donados tiene derecho a construirse una imagen de su propia identidad como cualquier otro ser humano. Vivimos en una sociedad mucho más abierta que la de hace veinte años. El secreto hoy dia ha de estar justificado".
} 
personal. Uno de ellos es el elemento genético. Para delimitar los alcances de un derecho a conocer los orígenes en la reproducción asistida, debemos desentrañar cuál es el grado de importancia que el elemento genético contiene en la construcción de la identidad de personas nacidas mediante el uso de estas técnicas.

Según un trabajo del Comité de Bioética de Catalunya:

La identidad del recién nacido se esboza en la realidad interna de la madre, e incluso durante la gestación. La interacción entre la madre y el niño está en buena parte determinada por la representación de la identidad del recién nacido en la mente de la madre y los intercambios emocionales y afectivos que el recién nacido mantiene con la madre van creando, organizando y sosteniendo las bases de la identidad del niño. Si aceptamos que la construcción de la identidad se inicia durante el embarazo y que, por lo tanto, hay un vínculo entre el niño y la madre gestante, el nacimiento es la gran fractura inicial que puede repararse en el momento satisfactorio de reencuentro "piel con piel" del recién nacido con su madre y quedará inscripta en la construcción del psiquismo del niño como la gran fractura o el gran "vacío". ${ }^{13}$

En los casos de la reproducción asistida heteróloga (práctica que precede a la gestación) parecería que la participación del donante no debería afectar sustancialmente la construcción de la identidad del nacido más allá de importar un simple dato genético, toda vez que madre y gestante, en este caso, son la misma persona. Distinto sería el supuesto especial de la gestación por sustitución, en donde resulta evidente que, al no lograr repararse la "fractura" con un reencuentro piel con piel, pues se desvincula al recién nacido de quien lo ha gestado y parido, tiene cierta incidencia en la construcción de la identidad de ese niño o niña.

Si bien no puede asegurarse a ciencia cierta el grado de importancia del 212 dato genético en la construcción de la identidad personal, existe un consenso generalizado en que tal información no puede quedar a la libre disposición de los Estados o centros especializados. Por el simple hecho de tratarse de uno de los elementos que conforman la identidad de una persona, debe ser resguardada y registrada. El Estado por sí sólo no puede ocultar a las personas el

\footnotetext{
${ }^{13}$ Cfr. Comité de Bioética de Catalunya, "El derecho a conocer los orígenes biológicos y genéticos de la persona", p. 5. Recuperado de: http://comitebioetica.cat/wp-content/uploads/2016/06/Derecho-a-conocer-los-origenes-biologicos-CBC1.pdf
} 
conocimiento sobre su origen, pues implicaría negarle uno de los elementos constitutivos de su identidad. Es la propia persona, con base en su autonomía personal, quien elegirá qué grado de importancia le dará a su vida conocer o no ese dato genético.

Como adelantamos, la discusión se situará en el cruce entre el derecho a conocer los orígenes y aquellas legislaciones que propician el anonimato en las donaciones y, en todo caso, en qué supuestos se habilitará a otorgar datos identificatorios y no identificatorios del o la donante.

El ejercicio de este derecho implica un proceso previo. Para ejercerlo se debe haber tomado conocimiento acerca de cómo fue la concepción, es decir, disponer de información que alguien debe propiciar. En otras palabras, si los progenitores no dicen nada al hijo sobre el origen de su concepción, éste no tiene manera, más allá del descubrimiento casual, de cuestionarse sus orígenes, excepto en supuestos fácticos donde tal cuestionamiento sea una obvia consecuencia de la propia organización familiar (monoparental u homoparental). El legislador, por lo tanto, deberá facilitar el ejercicio de este derecho a toda persona que desee conocer, ya sea regulando un deber de informar a los hijos sobre el origen biológico o la forma de concepción, o permitiendo que este dato conste en un documento separado del Registro Civil, o bien en el historial clínico del hijo.

\section{Secreto y anonimato. Intereses en conflicto}

En consonancia con lo sostenido por el Comité Consultivo Nacional de Ética de Francia, estamos en condiciones de afirmar que secreto y anonimato no cubren el mismo terreno. ${ }^{14} \mathrm{El}$ anonimato depende de la revelación del secreto, pues si el mismo se mantiene, el anonimato no puede siquiera plantearse. Podría decirse que existe una relación género-especie, en donde el secreto comprende no sólo el modo de concepción, sino también la identidad del donante. El secreto priva al niño de la oportunidad de preguntarse acerca de sus orígenes, pues existe una relación directa entre la revelación del secreto y la posibilidad de cuestionar el anonimato. Este último consiste en la reserva respecto de la identidad del donante. Éste es recíproco, tanto del donante como de los receptores de cualquier información relativa a su identidad. El anonimato se extiende a la imposibilidad de que estos datos los conozcan terceras personas, ajenas a las instituciones sanitarias o de conservación de gametos, lo que incluye a los

\footnotetext{
${ }^{14}$ Comité Consultatif National D'Ethique de Francia, "Acceso a los orígenes, anonimato y confidencialidad de la filiación". Disponible en: http://www.ccne-ethique.fr/docs/en/avis090.pdf
} 
nacidos a resultas de la donación. ${ }^{15}$

El ejercicio del derecho a conocer los orígenes exige un proceso previo mediante el cual se toma conocimiento acerca de cómo fue la concepción y que el legislador debe facilitar. Este mecanismo previo pone en evidencia el conflicto entre el derecho a conocer del hijo y el derecho a la intimidad personal de sus progenitores o del donante. Esta puja de derechos, que en principio parecerían encontrarse en un piso de igualdad, nos obliga a observar detenidamente cómo se afectan mutuamente. Ello nos lleva a concluir que la parte más vulnerable de estas relaciones humanas es la persona nacida mediante el uso de las TRHA, quien puede verse privada, por voluntad de otros, de uno de los elementos constitutivos de su identidad. El derecho al conocimiento es inherente al principio de autonomía y el derecho de libertad. Nadie puede suplantar la decisión o el deseo de una persona a conocer sus orígenes, sean genéticos o biológicos, fundado en el derecho a decidir cómo criar a los hijos o a la intimidad personal.

En el ámbito intrafamiliar, se considera conveniente y recomendable que las relaciones familiares estén regidas por la honestidad, fuertemente relacionada con valores como el amor y la transparencia en las relaciones humanas. ${ }^{16}$ Resulta ser perjudicial para cualquier relación humana que una persona tenga datos relevantes de la otra y los mantenga en secreto. Sin embargo, no en todos los casos los padres informan a sus hijos que han nacido a través de TRHA con donante, por lo tanto, el ejercicio del derecho a conocer sus orígenes. En esos casos, se verá cercenado, pues es imposible que la persona pueda decidir por sí misma al respecto.

Esto está relacionado directamente con el derecho a la verdad, el cual, según un documento emitido por la Comisión Interamericana de Derechos Humanos, ${ }^{17}$ se ha consolidado como una garantía establecida tanto en la Declaración Americana como en la Convención Americana. ${ }^{18}$ En el derecho internacional de los derechos humanos, se presenta en situaciones de violaciones masivas y sistemáticas de los derechos humanos, donde el Estado está obligado

\footnotetext{
${ }^{15}$ Herrera, Marisa y Lamm, Eleonora, "Técnicas de reproducción humana asistida", en Bioética en el Código Civil y Comercial de la Nación, p. 548.

${ }^{16}$ Nuffield Council on Bioethics. Donor Conception: ethical aspects of information sharing. London, 2013, p. 86 y sstes.

${ }_{17}$ CIDH, Derecho a la verdad en las Américas, 2014, p. 42. Disponible en: http://www.oas.org/es/cidh/informes/pdfs/ derecho-verdad-es.pdf

${ }^{18}$ Tanto la Comisión como la Corte Interamericana de Derechos Humanos han sostenido que el derecho a la verdad se vincula de manera directa con los derechos a las garantías judiciales y protección judicial, los cuales se encuentran establecidos en los artículos 18 y 24 de la Declaración Americana, asi como en los artículos 8 y 25 de la Convención Americana.
} 
a investigar, procesar y castigar a quienes resulten responsables, y a revelar a las víctimas y a la sociedad todo lo que pueda establecerse sobre los hechos ya las circunstancias de tales violaciones. ${ }^{19}$ Como podemos observar, tiene una doble dimensión. Por un lado, el derecho de las víctimas y familiares a conocer los hechos que dieron lugar a violaciones de derechos humanos; por el otro, a conocer la identidad de quienes participaron en ellos. Así, este derecho guarda una íntima relación con el derecho al acceso a la información.

Salvando las distancias con el contenido que el derecho internacional le ha brindado al derecho a la verdad, en relación con el derecho a conocer los orígenes, el Estado debe bregar, entre otras cosas, por el respeto a la identidad de las personas que lo integran. No puede ocultar aquellos canales de información que posibiliten el acceso a la historia de vida de las personas, lo que violaría radicalmente tal derecho humano y perjudicaría a los propios involucrados y terceros. Los Estados deben sustentarse en una organización social basada en la verdad, en el respeto por el otro y la transparencia. En otras palabras, es deber del Estado registrar y resguardar dicha información, a la cual podrá acceder el interesado cuando invoque razones que así lo justifiquen. Debe equilibrar el derecho a conocer los orígenes con el derecho a la intimidad personal de otras personas involucradas.

Revelar el secreto en torno a la concepción de ningún modo implica la necesidad de ir más allá del hecho de tener acceso a una información médica que pueda ser relevante en un futuro para la salud de la persona. Sin embargo, no genera la necesidad de conocer la identidad de los donantes de gametos que han hecho posible su existencia. La pretensión que busca extender el derecho a conocer hasta el punto de la identificación de los donantes debe encontrar justas razones, pues entra en conflicto directo con la intimidad personal del donante. Contrario sensu, la limitación y resguardo de la identidad, el anonimato, debe guardar una justificación razonable, pues entra en conflicto con el derecho a conocer los orígenes de la persona nacida a través de la reproducción asistida. ${ }^{20}$

La implicancia de los derechos humanos en cruce obliga a los Estados a realizar un necesario examen de proporcionalidad con el objeto de delimitar el alcance que tendrá el ejercicio de cada uno de ellos y, en definitiva, qué situaciones darán lugar al levantamiento de la reserva de la identidad del donante.

\footnotetext{
${ }^{19}$ Gil Dominguez, Andrés, "La verdad: un derecho emergente", La Ley, 1999, p. 219.

${ }^{20}$ Cfr. Comité de Biótica de Catalunya, "El derecho a conocer los orígenes biológicos y genéticos de la persona", p. 5. Recuperado de: http://comitebioetica.cat/wp-content/uploads/2016/06/Derecho-a-conocer-los-origenes-biologicos-CBC1.pdf
} 


\section{Diferentes posturas legislativas}

En la doctrina comparada, la discusión acerca de la existencia y los alcances del derecho a conocer los orígenes en la reproducción asistida no encuentra una solución unívoca, sino varias vertientes. Pueden visualizarse a grandes rasgos tres posturas diferentes. Una de ellas orientada a vedar toda posibilidad de ejercicio del derecho a conocer los orígenes.

Dicha postura considera que no puede reclamarse tal derecho en la reproducción asistida, toda vez que el recorrido hacia los orígenes de la identi$\mathrm{dad}$, en las personas nacidas mediante ella, tiene como destino final -y punto de partida - la voluntad procreacional expresada en el consentimiento previo, informado y libre; no existen otros elementos constitutivos de aquella. Se entiende que el dato genético no tiene relevancia alguna en la construcción de la propia identidad y, en consecuencia, no existe un derecho a conocer dicha información. Queda únicamente circunscripto el ejercicio de tal derecho a los casos de adopción.

Por el contrario, otras posturas consideran que el elemento genético por sí solo ya es importante y es uno de los tantos que conforman la identidad de la persona. Sin embargo, entre ellas existe una disparidad esencial, sobre todo desde el punto de vista del respeto por el derecho a la intimidad personal del donante. Una de ellas considera que el interesado puede acceder a información, pero de tipo no identificatoria, pues no puede transgredirse el derecho a la intimidad personal del donante. En la otra se abre el panorama, pues la persona puede acceder a todo tipo de información, incluso identificatoria, pues considera que no sólo es relevante el dato genético, sino también toda otra información acerca del donante.

A partir de estas tres visiones, las legislaciones han regulado el anonimato en la reproducción asistida con diversas aristas que pueden encontrarse incluso dentro de quienes siguen un mismo criterio. Así, están quienes se agrupan en la primera postura o en la intermedia, es decir, aquellos que defienden el ano-

216 nimato. Éstos basan su argumento en el impacto negativo que traería levantar dicho anonimato, pues el número de donantes disminuiría considerablemente frente al temor de verse protagonistas de futuros reclamos judiciales. En consecuencia, las familias que requieren las TRHA verían truncado su deseo de tener un hijo. Otro argumento en favor del anonimato se centra en la evaluación de los perjuicios o beneficios que traería la supresión del mismo. Llegan a la conclusión de que ocasionaría más perjuicios tanto a los nacidos mediante TRHA como al donante, pues ambos irrumpen de manera en sus respectivas vidas, $\mathrm{y}$ eso, claramente, trae consecuencias. 
Por otro lado, quienes se posicionan en favor de una política legislativa aperturista sostienen que tales argumentos, aunque tuvieren sustento empírico, resultan ser cuestionables. Nadie puede privar a una persona del derecho a conocer información constitutiva de su identidad, ni hacer juicios de valor sobre lo que puede o no ser relevante para las personas. Ello será privativo de cada ser humano, quien, desde su interior, es capaz de decidir para sí lo que considera más o menos importante para la construcción de su propia identidad, según lo que dicte su autonomía personal. Veremos a continuación cómo se ha resuelto esta cuestión en las legislaciones que han abordado el tema.

En Bulgaria, Bélgica, República Checa, Dinamarca, Francia, Grecia, Portugal y España, el anonimato está protegido por ley. No obstante, Bulgaria y Bélgica prevén excepcionalmente la donación de gametos de personas conocidas. ${ }^{21}$ Todo lo contrario sucede en Francia, donde, en aplicación estricta del resguardo del anonimato, si los comitentes traen a su propio donante únicamente podrán utilizarlo a través de un programa de donación cruzada en el cual se intercambian los donantes entre las parejas receptoras. ${ }^{22}$

Distinta es la visión que tienen Austria, Finlandia, Países Bajos, Noruega, Suecia, Suiza y Reino Unido acerca del anonimato. Han orientado sus legislaciones, de manera paulatina, hacia la apertura de la información, sin distinción entre identificatoria y no identificatoria. Prohíben las donaciones anónimas. Empero, es preciso destacar que estos países han trabajado durante varios años para generar una cultura de la donación, comenzando por un sistema legislativo mucho más restrictivo en cuanto al acceso de la información.

En otras legislaciones como las de Estados Unidos y Canadá existe una posición intermedia con una política denominada double track (doble vía). Permiten el acceso del nacido a datos identificativos del donante sólo cuando este último optó por una donación abierta. ${ }^{23}$ Los donantes pueden elegir si desean donar de manera anónima o no.

\footnotetext{
${ }^{21}$ En Bélgica, por ejemplo, todos los que trabajan dentro de la clínica de fertilidad están obligados al secreto profesional. Las excepciones a esta regla incluyen información acerca de las características físicas del donante que puede ser compartida con los beneficiarios al momento de elegir un donante; información médica que puede ser obtenida a petición de personas concebidos por donantes; y cuando donante y receptor solicitan mutuamente el no-anonimato (es decir, en la donación conocida).

${ }^{22}$ Herrera, Marisa y Lamm, Eleonora, "Técnicas de reproducción humana asistida", en Bioética en el Código Civil y Comercial de la Nación, p. 431.

${ }^{23}$ En este modelo se basan las directrices de la Sociedad Americana para la Medicina Reproductiva (ASRM), que son las que siguen la mayoría de los centros de TRHA en Estados Unidos. Propone diferentes niveles de información a los cuales pueden acceder los concebidos de esta forma, en función del consentimiento del donante cuando realizó la donación. Se puede optar por no identificativa; identificativa de contacto por motivos médicos; contacto personal no identificativo $y$, finalmente, contacto personal identificativo.
} 
Lo curioso de este modelo es que deja subordinado el derecho a conocer los orígenes al ejercicio que haga o no el donante de su derecho a la intimidad, pues depende exclusivamente de la opción que este último decida tomar. En otras palabras, tiene un peso más fuerte el derecho del donante a su intimidad que el derecho a conocer los orígenes de las personas nacidas a través de estas técnicas.

En Brasil, la resolución 2013/13 del Consejo Federal de Medicina ${ }^{24}$ establece la obligatoriedad de mantener el anonimato tanto de los donantes de gametos y embriones como de los receptores, excepto por razones médicas que así lo requieran. Puede brindarse la información únicamente por los médicos tratantes.

Por su parte, la ley de TRHA de Uruguay 19.167 de $2013,{ }^{25}$ en su artículo 12, dice: "La donación de gametos se realizará en forma anónima y altruista, debiendo garantizarse la confidencialidad de los datos de identidad de los donantes sin perjuicio de lo establecido en el artículo 21 de la presente ley". El artículo 21, referente a la identidad del donante, dice:

La identidad del donante será revelada previa resolución judicial cuando el nacido o sus descendientes así lo soliciten al Juez competente, de conformidad con lo dispuesto en los artículos 22, 23 y 24 de la presente ley. La información proporcionada no implicará en ningún caso la publicidad de la identidad de los donantes ni producirá ningún efecto jurídico en relación a la filiación. Son jueces competentes los Jueces Letrados de Primera Instancia de Familia de Montevideo y los Jueces Letrados de Primera Instancia del interior del país con competencia de Familia.

La acción referida en el artículo 21, según surge del artículo 23, "podrá ser ejercida por el nacido por aplicación de la técnica de reproducción humana asistida o sus representantes legales y, en caso de que hubiere fallecido, por sus descendientes en línea directa hasta el segundo grado, por sí o por medio de sus representantes".

\footnotetext{
${ }^{24}$ Conselho Federal de Medicina, "Resolução CFm, № 2.013/2013". [Consulta: 26 de septiembre, 2016]. Disponible en: http://www.portalmedico.org.br/resolucoes/CFM/2013/2013_2013.pdf

${ }^{25}$ Poder Legislativo de la República Oriental de Uruguay, "Ley No. 19.167". [Consulta: 26 de septiembre, 2016]. Disponible en: http://archivo.presidencia.gub.uy/sci/leyes/2013/11/msp_512.pdf
} 


\section{Postura del Código Civil y Comercial Argentino}

De los Fundamentos del Anteproyecto de Código Civil y Comercial de Argentina surgía:

La reforma regula otra cuestión que se deriva del uso de gametos de terceros como es el derecho a conocer los orígenes de los niños nacidos a través de estas técnicas [...] si bien el anteproyecto establece la regla del anonimato, prevé supuestos de apertura o flexibilización de dicho carácter. En efecto, se reconoce el derecho de las personas nacidas de este modo a obtener información médica sobre los donantes en caso de riesgo para la salud de los centros de salud, sin necesidad de intervención judicial. La identidad del donante, en cambio, puede ser develada cuando se invocan otras razones debidamente fundadas, que deben ser evaluadas por la autoridad judicial (no ya administrativa) en atención a los intereses en juego. De este modo, la reforma adopta una postura intermedia, frente a un panorama dispar en el derecho comparado. Se sigue de cerca la legislación española (ley 14/2006) pero se abre la posibilidad de abandonar el anonimato frente a razones fundadas que deben ser valoradas judicialmente. ${ }^{26}$

Cabe destacar que el Código Civil y Comercial entrado en vigencia el primero de agosto del 2015, incluye dentro del libro II, titulo 5, referido a la Filiación, el capítulo 2 que versa sobre las reglas generales relativas a la filiación por técnicas de reproducción humana asistida. Específicamente, los artículos 563 y 564 se encargan de regular lo relativo al derecho en análisis.

El articulo 563 Código Civil y Comercial reza: "La información relativa a que la persona ha nacido por el uso de técnicas de reproducción humana asistida con gametos de un tercero debe constar en el correspondiente legajo base para la inscripción del nacimiento". Por consiguiente, la única información que quedará registrada en el legajo base será que se ha nacido de una TRHA heteróloga. El resto de la información referida al donante deberá ser resguardada en el Registro Único y en cualquier otro registro que determine la ley especial.

La doctrina señala que el Código Civil y Comercial "reafirma la existencia de un derecho a la información y de su debido resguardo, a tal punto que es-

\footnotetext{
${ }^{26}$ Fundamentos del Anteproyecto de Código Civil y Comercial de Argentina. [Consulta: 29 de septiembre, 2016]. Disponible en: http://www.nuevocodigocivil.com/wp-content/uploads/2015/02/5-Fundamentos-del-Proyecto.pdf (El resaltado nos pertenece).
} 
tablece que en el legajo base sobre el cual se procede a inscribir el nacimiento de un niño debe constar que se trata de una persona que ha nacido de TRHA con material genético de un tercero; y todo registro en el que conste toda la información sobre dicho donante es materia de la regulación especial a la cual remite el CCyC en varias oportunidades". ${ }^{27}$

Es preciso señalar que en varias ocasiones el Código Civil y Comercial establece la necesidad de regular en una ley especial aspectos que hacen a las TRHA y que no correspondía tratar en una legislación de fondo. El artículo 564 se establece:

A petición de las personas nacidas a través de las técnicas de reproducción humana asistida, puede:

a. obtenerse del centro de salud interviniente información relativa a datos médicos del donante, cuando es relevante para la salud;

b. revelarse la identidad del donante, por razones debidamente fundadas, evaluadas por la autoridad judicial por el procedimiento más breve que prevea la ley local.

Como vemos, hay dos tipos de información que puede obtener el nacido por TRHA. Por un lado, está la información relativa a datos médicos, entre los cuales podemos nombrar enfermedades hereditarias, entre otros aspectos. Dicha información podrá obtenerse del centro de salud interviniente. Para ello no es preciso iniciar un proceso judicial, basta con requerirlo al centro por cuestiones relevantes para la salud. De ahí la importancia de sistematizar el modo en que los centros resguardan la información. Hasta la fecha, la falta de regulación al respecto implica que cada centro médico determine, sin control alguno por parte del Estado, de qué modo y bajo qué criterios se almacena y se conserva la información.

Por otro lado, el inciso b) del artículo en análisis establece que por razones “debidamente fundadas”, en este caso evaluadas por la autoridad judicial, 220 podrán develarse datos de la identidad del donante. De más está decir que la obtención de datos identificatorios del donante no implica en absoluto generar vínculo jurídico alguno, ni que sea plausible de reclamos.

Podemos destacar el proyecto de regulación especial de técnicas de reproducción humana asistida 0581-D-2014 y 4058-D-2014. ${ }^{28}$ Éste cuenta con la

\footnotetext{
${ }^{27}$ Herrera Marisa, "Comentario al Libro II", en Marisa Herrera, Gustavo Caramelo, Sebastián Picasso (dirs.), Código Civil en Código Civil y Comercial de la Nación Comentado, Buenos Aires, Infojus, 2015, p. 294.

28 "Ley Integral de Técnicas de Reproducción Humana Asistida", Diputados Argentina. [Consulta: 28 de septiembre,
} 
aprobación de la Cámara de Diputados con fecha 12 de noviembre de 2014. En su artículo 16 establece:

El aporte de gametos o embriones para terceros reviste carácter reservado y confidencial. Los centros de salud autorizados deben elaborar un legajo con los datos de identidad del o la aportante, incluyendo la información de carácter médico que surja del estudio clínico a que refiere el artículo $4^{\circ}$, dejando constancia de los antecedentes clínicos familiares que, bajo el modo de declaración jurada, informe el o la aportante.

El legajo del o la aportante reviste carácter confidencial. Este legajo podrá confeccionarse en soporte magnético siempre que se arbitren todos los medios que aseguren la preservación de su integridad, autenticidad, inalterabilidad, perdurabilidad y recuperabilidad de los datos contenidos en el mismo, debiendo adoptarse el uso de accesos restringidos con claves de identificación, medios no reescribibles de almacenamiento, control de modificación de campos o cualquier otra técnica idónea para asegurar su integridad y confidencialidad. El centro de salud autorizado debe conservar el legajo en forma permanente y se remitirá copia en soporte magnético al registro único, observando lo dispuesto en el artículo 20 de la presente ley. Asimismo en caso de nacimiento con vida deberá remitirse al Registro del Estado Civil y Capacidad de las Personas copia del legajo base para la inscripción del nacimiento [...] El contenido de la información de la identidad del donante sólo podrá ser revelado en los supuestos del artículo 564 del Código Civil y Comercial Unificado, teniendo en cuenta como razón fundada, entre otras, cuando haya un riesgo para la vida o para la salud física y psíquica de la persona nacida por técnicas de reproducción humana asistida.

El artículo 20 del mismo proyecto incorpora funciones al registro único establecido en el artículo 4 de la ley 26.862 y reglamentación vigente. Podemos destacar el inciso $\mathrm{d}$.

Confeccionar un legajo personal por cada aportante de gametos para terceros, respetando el principio de confidencialidad, que se elaborará con la información que deberán remitir los centros de salud autorizados, de acuerdo a lo dispuesto en el artículo 16 de la presente ley.

Los legajos personales deberán contener la siguiente información:

1. Identificación del aportante, acreditada mediante copia de documento de identidad.

2. Copia del convenio celebrado con el centro de salud autorizado. 
3. Copia del consentimiento informado.

4. Copia de los estudios clínicos realizados y toda otra información médica relevante.

5. Fecha en que se realizó el depósito del material genético.

6. Destino del material genético, debiendo quedar registradas las personas que resultaron beneficiarias de los gametos y el consentimiento informado de éstas; $y$, en caso de que resultare un procedimiento exitoso, se deberá proceder a la anotación del o de los partos, identificando la o las personas nacidas.

7. Material genético cuya crioconservación cesara conforme lo dispuesto en el artículo 11 de la presente ley.

8. Toda otra información que resulte de utilidad a criterio de la autoridad de aplicación.

Tal como se aprecia en el proyecto de ley que citamos, es justamente en la ley especial de TRHA donde se definen las funciones de los registros, la información que deben contener los legajos y otras cuestiones sobre la confidencialidad y al acceso a la información.

En octubre de 2015 se realizaron las XXV Jornadas Nacionales de Derecho Civil. En la comisión 6, Familia: “Identidad y filiación”, se debatió la regulación del Código Civil y Comercial en materia de TRHA y derecho a conocer los orígenes. Se concluyó por unanimidad la "Necesidad de que el Estado (Ministerio de Salud) crea y mantenga actualizado el Registro Único de donantes, eslabón necesario para efectivizar el derecho de acceso a la información contemplado en el art. 564 del CCyCN en una ley especial". También por unanimidad se estableció "El deber del centro de salud de resguardar datos sobre el donante". ${ }^{29}$

Tal como señalamos anteriormente, el Código Civil y Comercial estableció en su artículo 564 el derecho de los niños nacidos por TRHA a conocer sus orígenes. En consonancia con el modelo de anonimato relativo, el articulado diferencia entre datos identificatorios y no identificatorios del donante. En

222 principio, la donación es anónima, pero puede, ante circunstancias particulares, develarse determinada información.

Quien resulte interesado puede requerir los datos no identificatorios (información médica, genética) en forma directa al centro médico donde se realizó la técnica. Este deberá conservarla tal como lo determine la ley especial. Por otro

\footnotetext{
${ }^{29}$ XXV Jornadas Nacionales de Derecho Civil, Bahía Blanca 2015. [Consulta: 26 de septiembre, 2016]. Disponible en: http://jndcbahiablanca2015.com/wp-content/uploads/2015/10/CONCLUSIONES-06.pdf
} 
lado, los datos identificatorios (nombre, apellido, dirección, teléfono) sólo podrán develarse previa instancia judicial, y siempre que exista una justificación suficiente. En este sentido, mucho se debatió respecto a cuáles podrían ser los argumentos que se consideren justificadores del levantamiento del anonimato.

Así, en las XXV Jornadas Nacionales de Derecho Civil se concluyó que: "En el art. 564 inc. b del Código Civil y Comercial de la Nación se debe entender las 'razones debidamente fundadas' de manera amplia y flexible". ${ }^{30}$ Ya desde el año 2014 existen pronunciamientos judiciales que resaltan la importancia de conservar los datos de los donantes para garantizar en el futuro el acceso de las personas nacidas por TRHA a sus orígenes.

En forma breve resumiremos el caso. La señora EMC y el señor MBZ, por derecho propio y en representación de sus dos hijas menores de edad, promueven acción contra el Poder Ejecutivo Nacional con el objeto de que, a través del Ministerio de Salud, o del organismo que se considerara competente, se cree un registro con toda la información de los centros de fertilidad y bancos de gametos legalmente habilitados en el país sobre la identidad de los donantes de gametos. En el caso en cuestión, las hijas nacieron por ovodonación. La finalidad era que sus hijas y todas las personas nacidas por fertilización asistida con material heterólogo pudieran, al cumplir la mayoría de edad, ejercer su derecho a conocer su identidad biológica y acceder a esa información con la correspondiente autorización judicial.

Los demandantes basaron su solicitud en la necesidad de preservar dicha información. Dado que nuestro país no cuenta con legislación respecto al tema, ni los centros de fertilidad ni los bancos de donantes se encuentran obligados a conservar esta información. Fundaron su petición en el derecho a la salud, a la procreación, a la protección de la familia y a la identidad.

La Sala V de la Cámara Nacional de Apelaciones en lo Contencioso administrativo Federal, el 29 de abril de 2014, ${ }^{31}$ resolvió:

Hacer lugar, también en parte, a la demanda de amparo; y ordenar al Estado Nacional [Ministerio de Salud de la Nación] que arbitre los medios que estime más convenientes a fin de preservar de manera efectiva la información relativa a la donante de los óvulos utilizados para llevar a cabo el procedimiento de fertilización asistida al que se refiere el

\footnotetext{
${ }^{30}$ XXV Jornadas Nacionales de Derecho Civil, Bahía Blanca 2015. [Consulta: 26 de septiembre, 2016]. Disponible en: http://jndcbahiablanca2015.com/wp-content/uploads/2015/10/CONCLUSIONES-06.pdf

${ }^{31}$ Cámara Nacional de Apelaciones en lo Contencioso Administrativo Federal, Sala V, "C., E. M. y Otros c. EN-M. Salud s/ amparo Ley 16.986". Disponible en: http://www.derecho.uba.ar/institucional/deinteres/2014-fallo-cem.pdf
} 
presente caso, ya sea mediante el dictado de un acto administrativo de alcance particular o general, sin dar acceso a ella a la parte interesada y exclusivamente con el objeto de que sea utilizada en las condiciones y modalidades que oportunamente establezca el Congreso de la Nación al dictar la reglamentación legal correspondiente a esta materia.

Como se puede advertir, la resolución distingue dos aspectos del derecho a conocer los orígenes. Por un lado, distingue el derecho a conservar la información respecto del donante; por el otro, el derecho a tener acceso a la información que fue conservada.

En consonancia con el principio de autonomía progresiva que atraviesa el Código Civil y Comercial, el acceso a la información no identificatoria no setablece una edad mínima. Puede hacerlo cuando cuente con edad y grado de madurez suficiente. Se presume que el mismo hecho de que un niño o adolescente se acerque al centro médico para obtener la información respecto del donante refleja un interés. Seguramente, en la práctica, no serán los niños pequeños quienes se acerquen para saber esta información. Pero es importante destacar que el desconocimiento de los orígenes no facilita esta acción.

Saber que se nació a través de la utilización de TRHA permite a los niños, niñas y adolescentes preguntarse un mañana acerca de su origen genético. Son los padres quienes deben asegurar en primera instancia dicho derecho a sus hijos. El modo en que estas circunstancias serán develadas depende de cada niño en particular, de su grado de madurez y de las preguntas que él mismo realice.

En cuanto a los datos identificatorios (nombre, apellido, domicilio, teléfono) el Código Civil y Comercial plantea ciertas limitaciones que están dadas en el tener que iniciar un proceso judicial, tal como lo hemos expuesto precedentemente. Marisa Herrera señala que "La postura legislativa que adopta el Código Civil y Comercial en lo que respecta al acceso de la información identificatoria, es decir, nombre y apellido, domicilio, teléfono y cualquier otro dato que permita dar con el paradero de la persona que en su momento donó 224 material genético, se entiende que es constitucionalmente válida al pretender alcanzar una solución equilibrada". ${ }^{32}$

El Estado debe garantizar que dicha información, tanto identificatoria como no identificatoria, se encuentre disponible, con el objeto de revelar el anonimato de ser preciso.

${ }^{32}$ Herrera Marisa, Manual de Derecho de las Familias, Buenos Aires, Abeledo Perrot, 2015, p. 539. 


\section{Palabras de cierre}

El derecho a conocer los orígenes en las TRHA tiene como contra cara el derecho a la intimidad personal. El cruce de estos derechos y la interpretación que se haga de los mismos fijarán la postura legislativa y delimitarán el proceso en la materia.

No obstante, tratándose de derechos humanos, estamos en condiciones de afirmar que los Estados deben respetar un piso mínimo que garantice el respeto y eventual ejercicio de ambos derechos. De esta manera, independientemente de la postura legislativa que se vaya a adoptar, resulta innegable que los datos de los donantes revisten importancia. Es deber de los Estados resguardar y reservar dicha información por respeto a la autonomía personal de cada uno de los individuos y en el entendimiento de que no tiene injerencia alguna para presumir de antemano qué dato puede llegar a ser significante o constitutivo de la identidad de una persona.

En este orden de ideas, no sólo alcanzará con el resguardo y la reserva de la mentada información, sino que, además, un siguiente paso será prever canales o vías de acceso a la misma, en mayor o menor grado, dependiendo de la postura legislativa que se adopte.

Un trabajo previo será la revelación del secreto. Los Estados deben optar a partir de qué momento abordan la cuestión. Uno de los problemas de la legislación argentina es que no se obliga a los progenitores a develar el secreto, sino que simplemente se hace constar en documento separado al acta de nacimiento que ha nacido mediante reproducción asistida con donante anónimo. Sin embargo, en la particular circunstancia del derecho argentino, creemos que, siendo que el elemento volitivo (voluntad procreacional) funda el vínculo jurídico filial, resulta coherente que el Estado no se inmiscuya de manera prematura y otorgue una importancia al elemento genético que la ley no brinda.

Argentina se sitúa en una posición intermedia, con un anonimato relativo. Prevé dos supuestos de acceso a la información: una vía administrativa para la obtención de datos no identificatorios y una vía judicial para obtener datos identificatorios. En este segundo supuesto, si bien de la lógica del Código Civil y Comercial argentino, no existe un derecho a conocer los orígenes por TRHA, porque no existe un bios (sumado a que el elemento fundante del vínculo filial es la voluntad procreacional). Esta es la clave para equilibrar el sistema de donaciones anónimas: garantizar y nivelar el derecho a la intimidad personal del donante con el derecho de aquellas personas nacidas por TRHA de conocer su origen genético. 
No obstante, el gran acierto, a nuestro entender, está dado en que el interesado debe dar razones debidamente fundadas ante la autoridad judicial competente. Es decir, no alcanza con la mera invocación de la pretensión de conocer el origen genético, sino que debe estar fundado en "justos motivos". Éstos pueden traducirse en un sentir profundo que permita suponer que el elemento genético realmente resulta constitutivo de su identidad y, una vez desenmascarado, obtendrá la plenitud que busca. En esos supuestos, el derecho a la intimidad personal de los donantes cederá frente al derecho a conocer los orígenes.

El gran problema que acontece en la actualidad legislativa argentina radica en la necesidad de contar una ley especial que cree un Registro Único de donantes. El propósito es que el Estado resguarde y reserve la información. Sin ello, se obstaculiza la garantía y el respeto de los derechos en juego. Finalmente, creemos que el Estado no debe tener injerencia en la autonomía personal de las personas. El dato genético puede tener un valor subjetivo para las personas nacidas por TRHA. Así, debe ofrecer alguna vía de excepción para aquellos supuestos en donde se pretenda la obtención de datos identificatorios.

\section{Bibliografía}

Cámara Nacional de Apelaciones en lo Contencioso Administrativo Federal, Sala V, “C., E. M. y Otros c. EN-M. Salud s/ amparo Ley 16.986”. Disponible en: http:// www.derecho.uba.ar/institucional/deinteres/2014-fallo-cem.pdf

CIDH, Contreras y otros vs. El Salvador, 31 de agosto, 2011. Disponible en: http:// corteidh.or.cr/docs/casos/articulos/seriec_232_esp.pdf

CIDH, Gelman vs. Uruguay, 24 de febrero, 2011. Disponible en: http://www.corteidh. or.cr/cf/jurisprudencia2/ficha tecnica.cfm?lang=en\&nId Ficha=345

CIDH, Derecho a la verdad en las Américas, 2014, p. 42. Disponible en: http://www. oas.org/es/cidh/informes/pdfs/derecho-verdad-es.pdf

Comité Consultatif National D’Ethique de Francia, “Acceso a los orígenes, anonimato y confidencialidad de la filiación”. Disponible en: http://www.ccne-ethique. fr/docs/en/avis090.pdf

Comité de BioÉtica de Catalunya, "El derecho a conocer los orígenes biológicos y genéticos de la persona". Recuperado de: http://comitebioetica.cat/wp-content/ uploads/2016/06/Derecho-a-conocer-los-origenes-biologicos-CBC1.pdf

Comité JuRídico InTERAmericano, "Opinión sobre el alcance del derecho a la identidad", 71 ${ }^{\circ}$ Período ordinario de sesiones, Documento CJI/doc. 276/07 Río de Janeiro, Brasil, rev. 1, de 10 de agosto de 2007.

Conselho Federal de Medicina, “Resolução cFm, № 2.013/2013”. [Consulta: 26 de septiembre, 2016]. Disponible en: http://www.portalmedico.org.br/resolucoes/ CFM/2013/2013_2013.pdf 
Fernández Sessarego, Carlos, Derecho a la Identidad personal, Argentina, Astrea, 1992.

Fundamentos del Anteproyecto de Código Civil y Comercial de Argentina. [Consulta: 29 de septiembre, 2016]. Disponible en: http://www.nuevocodigocivil. com/wp-content/uploads/2015/02/5-Fundamentos-del-Proyecto.pdf

GiL Dominguez, Andrés, “La verdad: un derecho emergente”, La Ley, 1999.

Herrera Marisa, “Comentario al Libro II”, en Marisa Herrera, Gustavo Caramelo, Sebastián Picasso (dirs.), Código Civil en Código Civil y Comercial de la Nación Comentado, Buenos Aires, Infojus, 2015

Herrera Marisa, Manual de Derecho de las Familias, Buenos Aires, Abeledo Perrot, 2015.

Herrera, Marisa y Lamm, Eleonora, "Técnicas de reproducción humana asistida”, en Bioética en el Código Civil y Comercial de la Nación.

“Ley Integral de Técnicas de Reproducción Humana Asistida”, Diputados Argentina. [Consulta: 28 de septiembre, 2016]. Disponible en: http://www.diputados. gob.ar/proyectos/proyectoTP.jsp?id=163835

OEA, "Programa Interamericano para el Registro Civil Universal y 'Derecho a la Identidad”, resolución $\mathrm{AG} / \mathrm{RES} .2286$.

OEA, "Programa Interamericano para el Registro Civil Universal y ‘Derecho a la Identidad”, resolución AG/RES. 2362.

OEA, "Programa Interamericano para el Registro Civil Universal y 'Derecho a la Identidad'”, resolución AG/RES. 2602

Poder Legislativo de la República Oriental de Uruguay, “Ley No. 19.167”. [Consulta: 26 de septiembre, 2016]. Disponible en: http://archivo.presidencia.gub.uy/sci/ leyes/2013/11/msp_512.pdf

XXV Jornadas Nacionales de Derecho Civil, Bahía Blanca 2015. [Consulta: 26 de septiembre, 2016]. Disponible en: http://jndcbahiablanca2015.com/wp-content/uploads/2015/10/CONCLUSIONES-06.pdf 
२28 